\title{
Preliminary report of the 2011 off the Pacific coast of Tohoku Earthquake
}

\author{
$\operatorname{AUTHOR}(\mathrm{S}):$
}

Takewaki, Izuru

\section{CITATION:}

Takewaki, Izuru. Preliminary report of the 2011 off the Pacific coast of Tohoku Earthquake. Journal of Zhejiang University SCIENCE A 2011, 12(5): 327-334

\section{ISSUE DATE:}

2011-05

URL:

http://hdl.handle.net/2433/159442

\section{RIGHT:}

The final publication is available at www.springerlink.com; This is not the published version. Please cite only the published version.; この論文 は出版社版でありません。引用の際には出版社版をご確認ご利用くだ さい。 


\title{
Preliminary report of the 2011 off the Pacific coast of Tohoku earthquake
}

\author{
Izuru TAKEWAKI \\ Department of Architecture and Architectural Engineering, Kyoto University \\ Kyotodaigaku-Katsura, Nishikyo-ku, Kyoto 615-8540, Japan \\ takewaki@archi.kyoto-u.ac.jp
}

\begin{abstract}
March 11, 2011, the East Japan was attacked by the 2011 off the Pacific coast of Tohoku earthquake (the Great East Japan earthquake). Almost 30,000 people were killed or missing by that earthquake and the subsequent monster Tsunami as of April 11, 2011. This paper reports several aspects of this devastating earthquake. It has been reported that long-period ground motions, which had been predicted by many researchers, occurred at Tokyo, Nagoya and Osaka. The response characteristics of high-rise buildings to the recorded long-period ground motions are discussed from the viewpoint of resonance and critical excitation. It is shown that high-hardness rubber dampers are very effective for the reduction of vibration duration in addition to the reduction of vibration amplitude.
\end{abstract}

Key words: earthquake, disaster, long-period ground motion, high-rise building, critical excitation, Tsunami

\section{INTRODUCTION}

The most devastating, killer earthquake in Japan after the 1923 Great Kanto earthquake occurred March 11, 2011 (Architectural Institute of Japan (2011)). The moment magnitude is 9.0 which is the largest so far in Japan. It is said that the recording system for low-frequency component of ground motions was not sufficient in Japan and records outside Japan were used to determine the magnitude. Almost 30,000 people were killed or missing by that earthquake and the subsequent monster tsunami as of April 11, 2011. The maximum height of the tsunami is reported to be almost $40 \mathrm{~m}$. It is remarkable in this earthquake that the number of collapsed or damaged buildings and houses remains not clear because most of the damages result from the tsunami.

This paper explains the characteristics of that earthquake and discusses the response characteristics of assumed super high-rise buildings (40 and 60-story) in Shinjuku, Tokyo during this earthquake from the viewpoint of long-period ground motion. The issue of long-period ground motion and its impact on building structural design was raised in Mexico, USA and Japan during 1980-1990s (for example, Heaton et al. 1995, Kamae et al. 2004, Ariga et al. 2006). A set of simulated long-period ground motions was provided in December, 2010 by the Japanese Government (the Ministry of Land, Infrastructure, Transport and Tourism (MLIT) (2010)) for the retrofit of existing high-rise buildings and as a design guideline for new high-rise buildings. In this paper assumed 40-story and 60-story steel buildings are subjected to the long-period ground motion recorded in Shinjuku, Tokyo during the 2011 off the Pacific coast of Tohoku 
earthquake.

The criticality of the long-period ground motions can be investigated based on the theory of critical excitation (Drenick 1970, Takewaki 2004, 2006). This theory is intended to overcome the difficulty resulting from the uncertainty of earthquake ground motions (Geller et al. 1997, Stein 2003). The credible bounds of input energy responses are obtained by using the critical excitation method with the constraints on acceleration and velocity powers. It is shown that the long-period ground motions can be controlled primarily by the velocity power and the ground motion recorded in Tokyo during the 2011 off the Pacific coast of Tohoku earthquake actually included fairly large long-period wave components.

\section{CHARACTERISTICS OF THE 2011 OFF THE PACIFIC COAST OF TOHOKU EARTHQUAKE}

First the characteristics of the 2011 off the Pacific coast of Tohoku earthquake are described. The fault slip area and the slip magnitude are shown in Fig.1. The comparison of slip fault size is shown in Fig.2 among the Sumatra earthquake 2004, the Great Kanto earthquake 1923, the Hyogoken-Nanbu earthquake 1995 and the Off the Pacific coast of Tohoku earthquake 2011. Because the fault slip area was huge in this earthquake, extremely wide areas in the East Japan were affected by this earthquake. The representative ground motions along the Pacific coast of East Japan are illustrated in Fig.3. It can be observed that two or more wave forms exist in some areas and the duration of most ground motions is over 2 minutes. This means that the fault slips occurred repeatedly in wide areas. Actually it is reported that three main fault slips occurred in this series of events. Fig.4 indicates the epicenter map of earthquakes during 30 days after March 10. The maximum ground accelerations and velocities from K-NET and KiK-net (NIED, Japan) are shown in Fig.5. It is reported that the ground acceleration over 2.5g was recorded in Tsukidate, Kurihara City, Miyagi Prefecture (see Fig.6). However it is also made clear (Fig.7) that the predominant period of this ground motion is smaller than 0.3(s) and this ground motion did not affect most buildings so much.

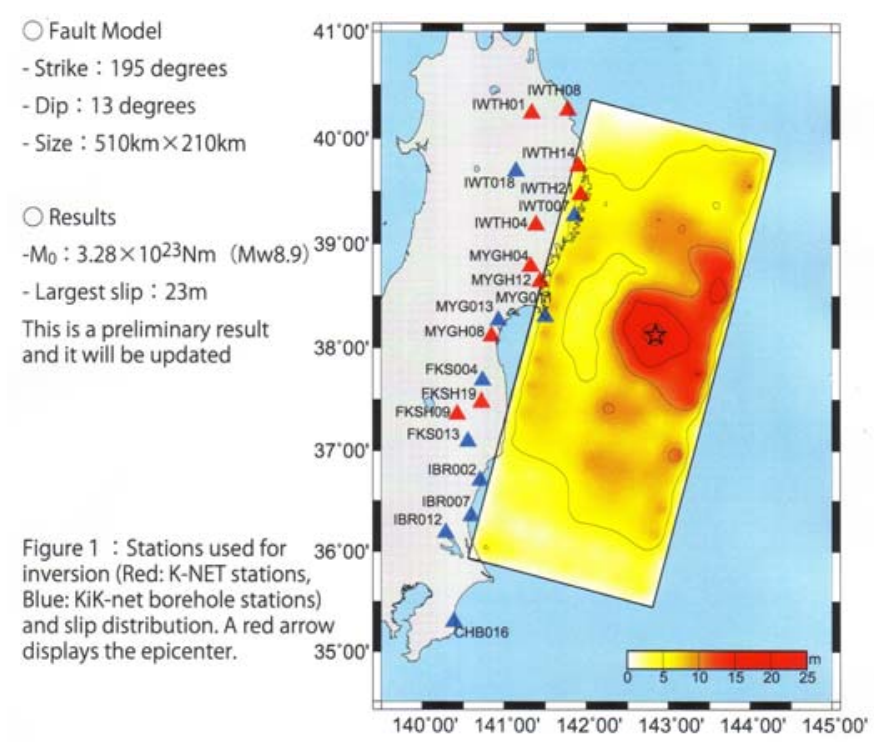

Fig.1 Stations used for inversion and slip distribution (arrow indicates the epicenter) taken from NIED (2011a) 


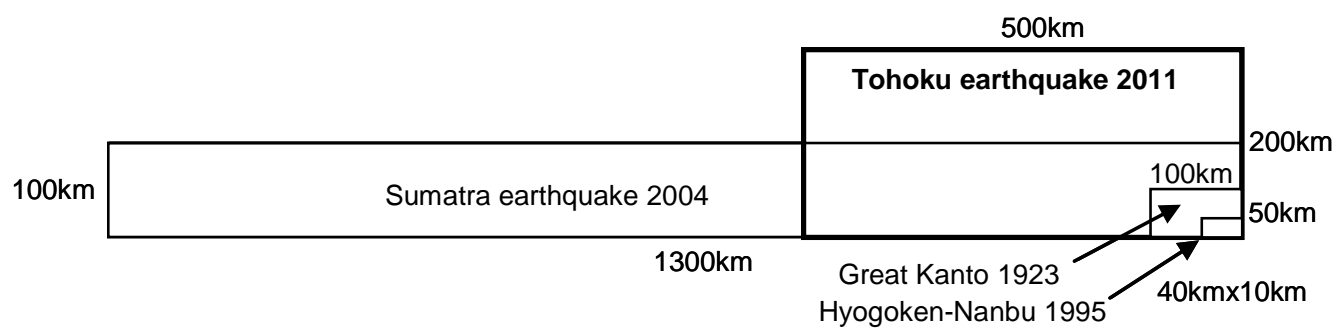

Fig.2 Comparison of slip fault size among Sumatra earthquake 2004, Great Kanto earthquake 1923, Hyogoken-Nanbu earthquake 1995 (Kobe) and Off the Pacific coast of Tohoku earthquake 2011 (data from Asahi newspaper (2011a))



Fig.3 Characteristics of ground motions taken from NIED (2011a) 


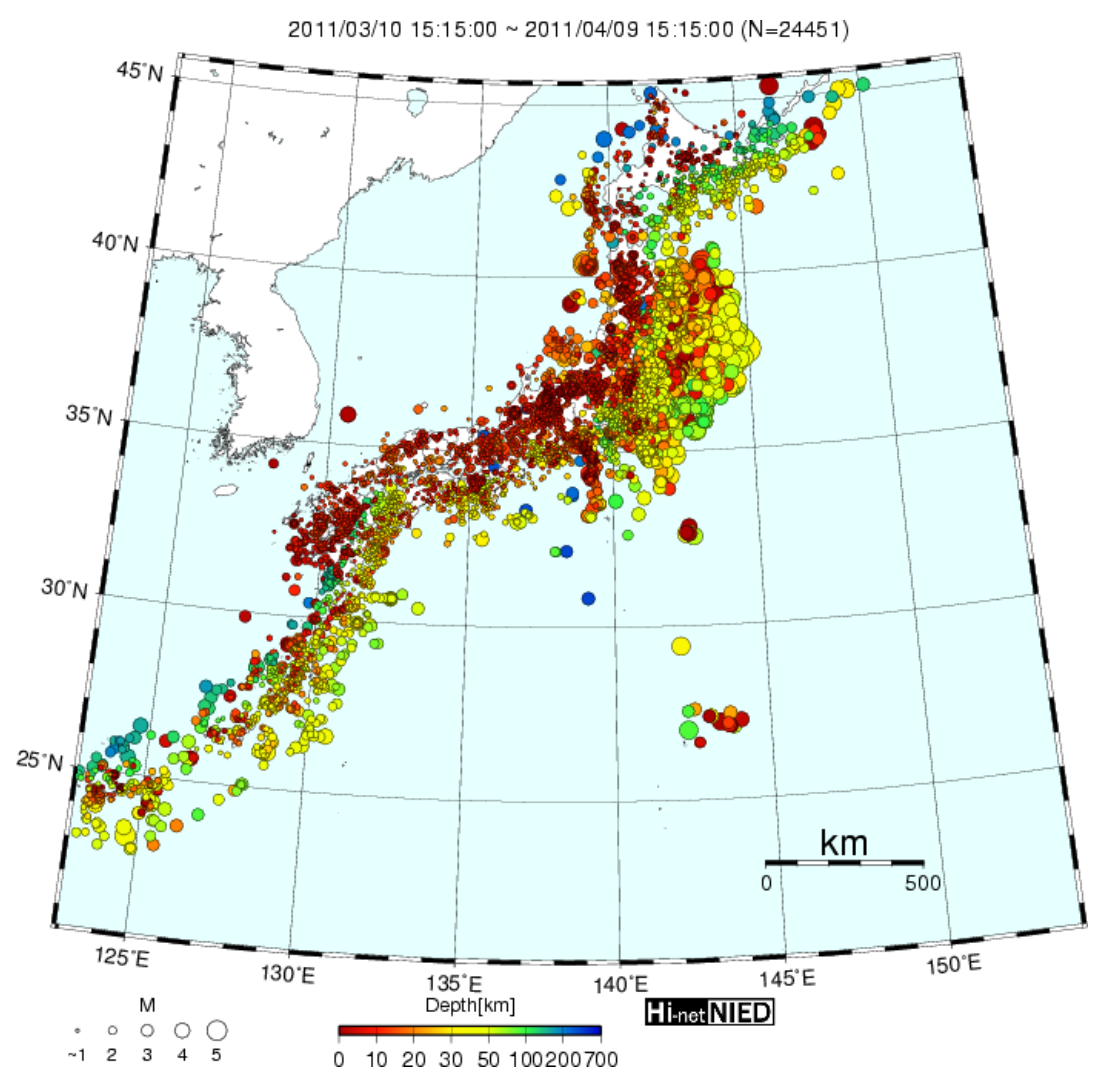

Fig.4 Epicenter map during 30 days after March 11 taken from NIED (2011b)

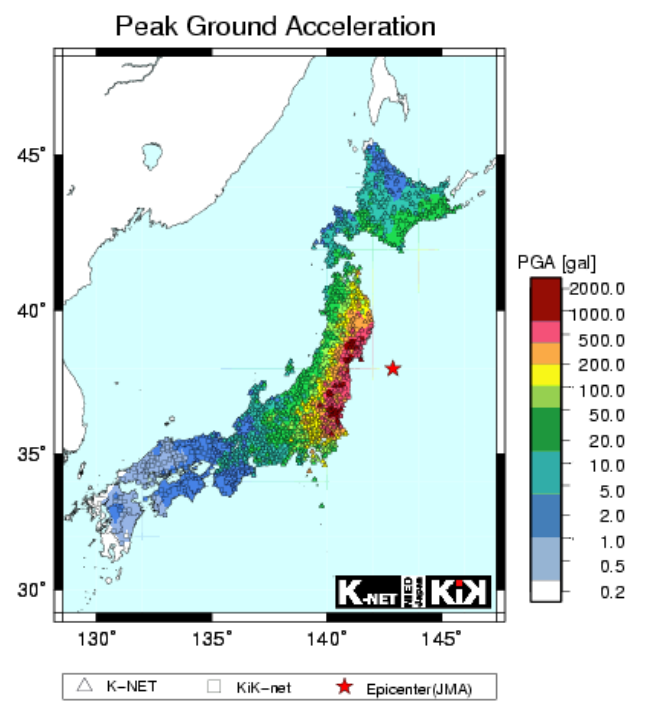

2011/03/11-14:46 38.0N 142.9E 24km M9.0

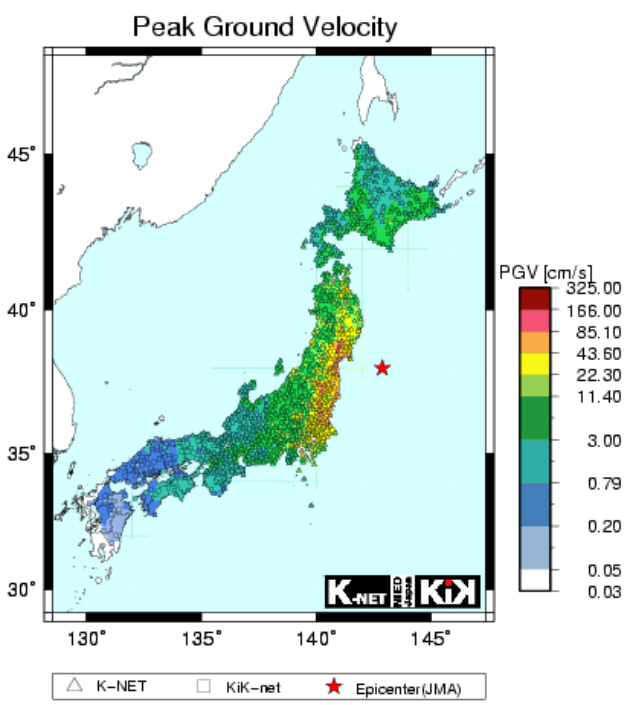

2011/03/11-14:46 38.0N 142.9E 24km M9.0

Fig.5 Maximum ground acceleration and velocity from K-NET and KiK-net taken from NIED (2011c) 


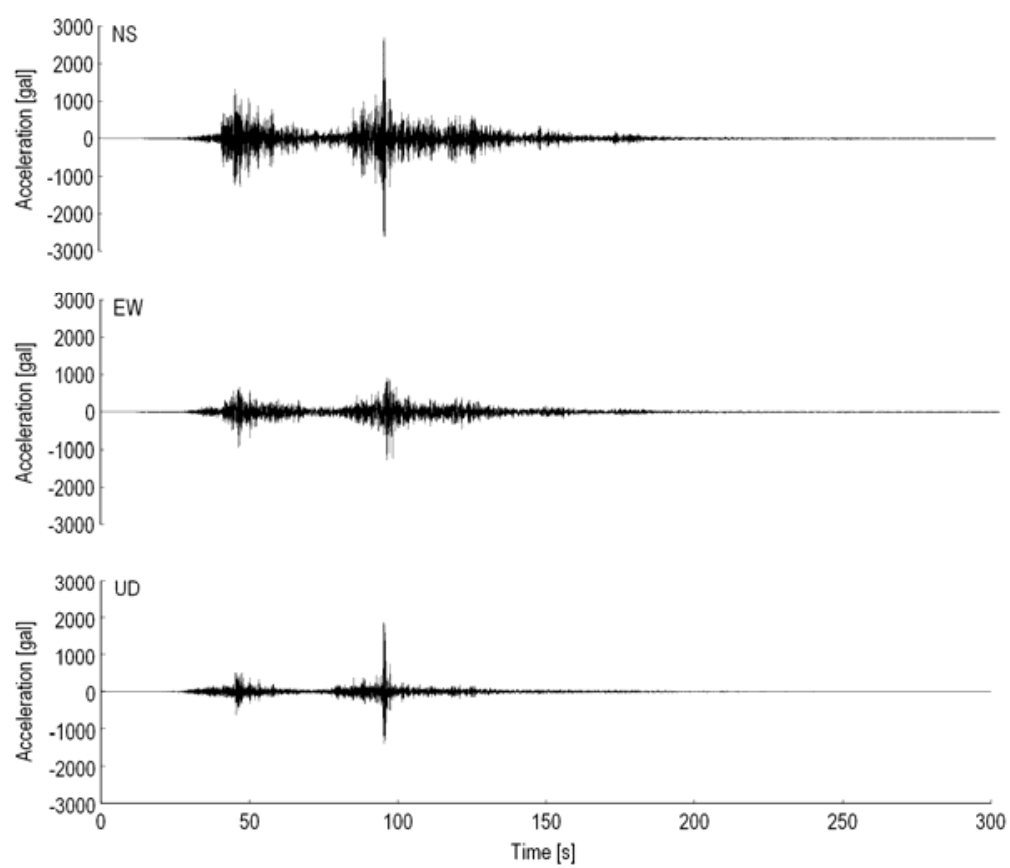

Fig.6 Acceleration record at Tsukidate (MYG004) in Kurihara City, Miyagi Pref. exhibiting the maximum ground acceleration (2933gal: synthesized from three components) among those in K-NET and KiK-net stations taken from NIED (2011c)
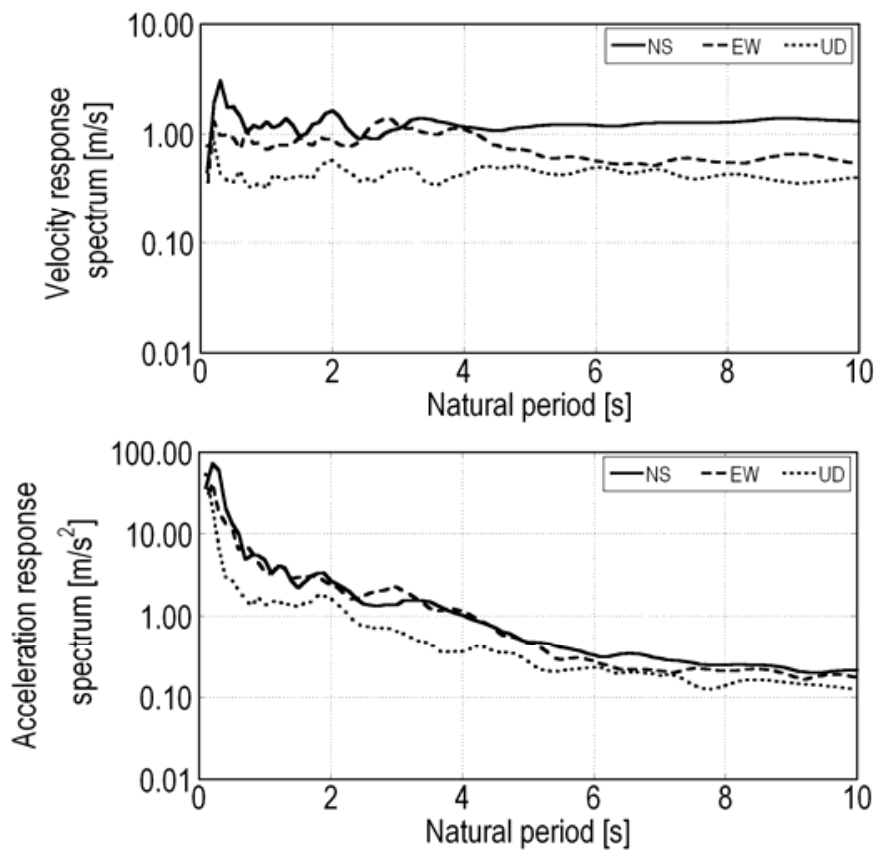

Fig.7 Velocity and acceleration response spectra for 5\% damping of the ground motions recorded at Tsukidate (MYG004) taken from NIED (2011c) 


\section{RESPONSE SIMULATION OF SUPER HIGH-RISE BUILDINGS IN TOKYO}

\section{Ground motions in Tokyo}

Fig.8 shows the velocity waveforms of the long-period ground motion recorded at K-NET, Shinjuku station (TKY007). It can be observed that the maximum ground velocity attains about $0.25(\mathrm{~m} / \mathrm{s})$ and the ground shaking continues for over several minutes. The corresponding velocity response spectra are shown in Fig.9. It is understood that shaking of period of 5-6 seconds is predominant in addition to 2 seconds.

In order to investigate further the characteristics of that record, the Fourier amplitude spectra of acceleration and velocity records have been computed. Fig.10 shows the Fourier amplitude spectra of accelerations and Fig.11 illustrates those of velocities. It can be observed that the velocity is predominant in longer period ranges. Fig.12 presents the comparison of the actual input energies (5\% damping), the credible bounds (Takewaki 2004, 2006) for acceleration constraints (acceleration power (Housner and Jennings 1977)) and the credible bounds for velocity constraints (velocity power (Housner and Jennings 1977)) for (a) NS component and (b) EW component. The intersection point indicates the predominant period. 4 and 6 seconds are such predominant periods and this supports that the ground motion recorded at K-NET, Shinjuku station (TKY007) actually included fairly large long-period wave components. For comparison, Fig.13 shows the corresponding figures for El Centro NS 1940 and JMA Kobe NS 1995 (Hyogoken-Nanbu earthquake). The intersection point exists in rather shorter period ranges.

\section{Long Period Ground Motion recorded at K-NET, Shinjuku station (TKY007)}

TKY007 2011/03/11 14:47:09

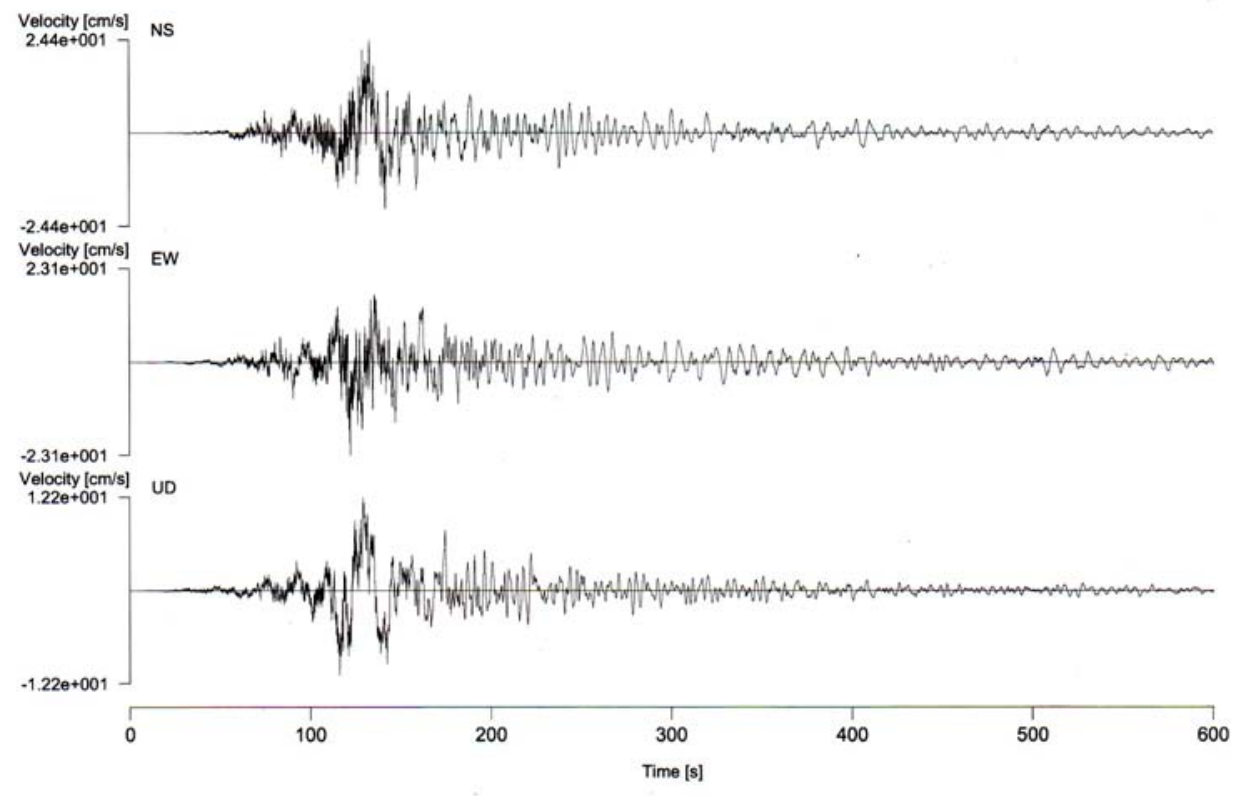

Fig.8 Long-period ground motion recorded at K-NET, Shinjuku station (TKY007) taken from NIED (2011a) 
Velocity Response Spectra (5\% damping)


Velocity Response Spectra (1\% damping)
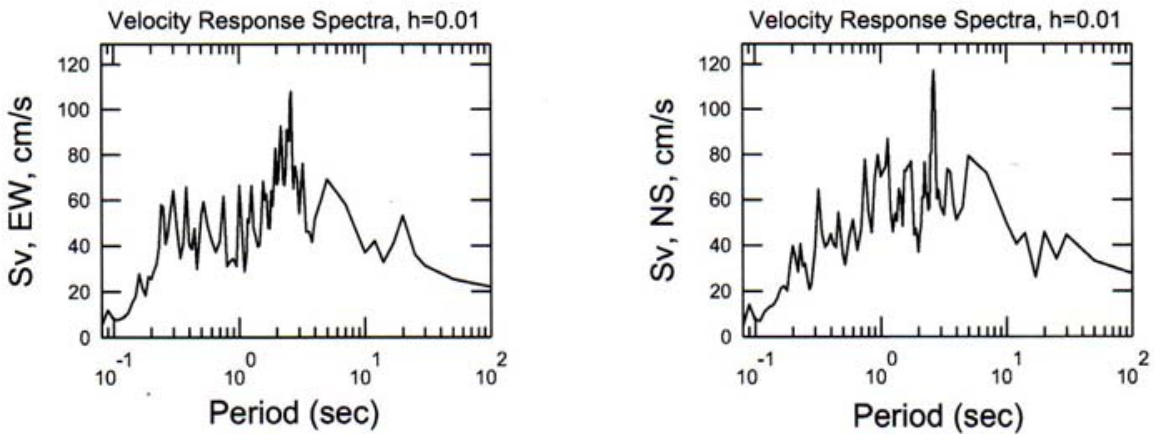

Fig.9 Velocity response spectra of ground motions at Shinjuku station (TKY007) taken from NIED (2011a)

(a)

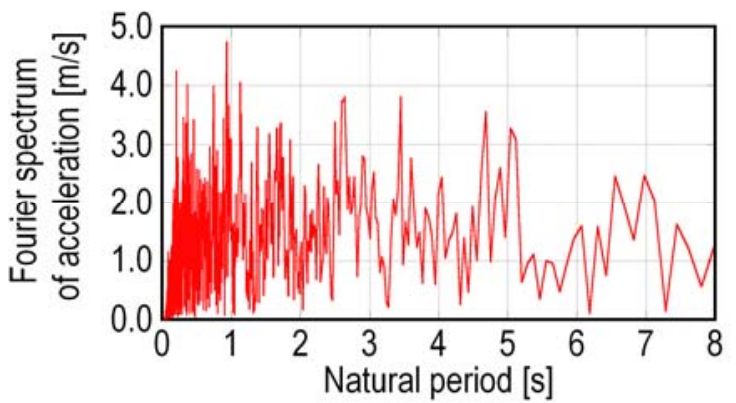

(b)



Fig.10 Fourier amplitude spectra of acceleration ground motion at K-NET, Shinjuku station (TKY007): (a) NS component, (b) EW component 
(a)

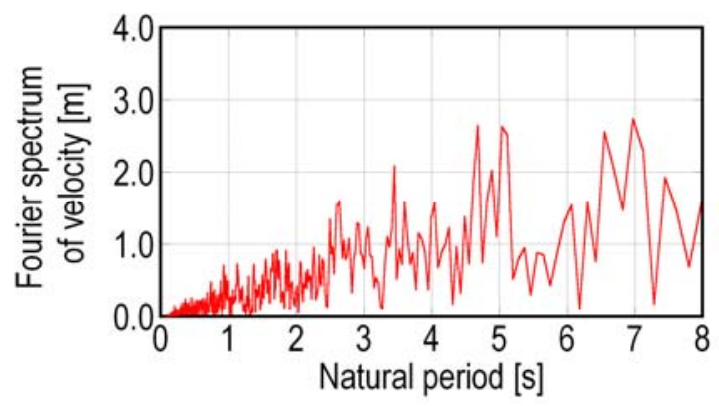

(b)

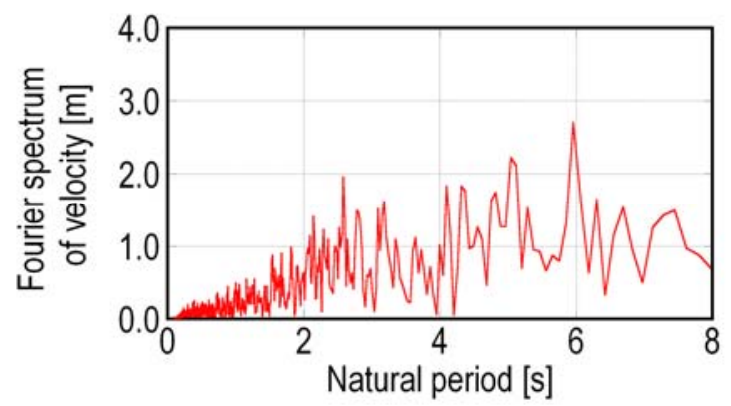

Fig.11 Fourier amplitude spectra of velocity ground motion at K-NET, Shinjuku station (TKY007): (a) NS component, (b) EW component

(a)

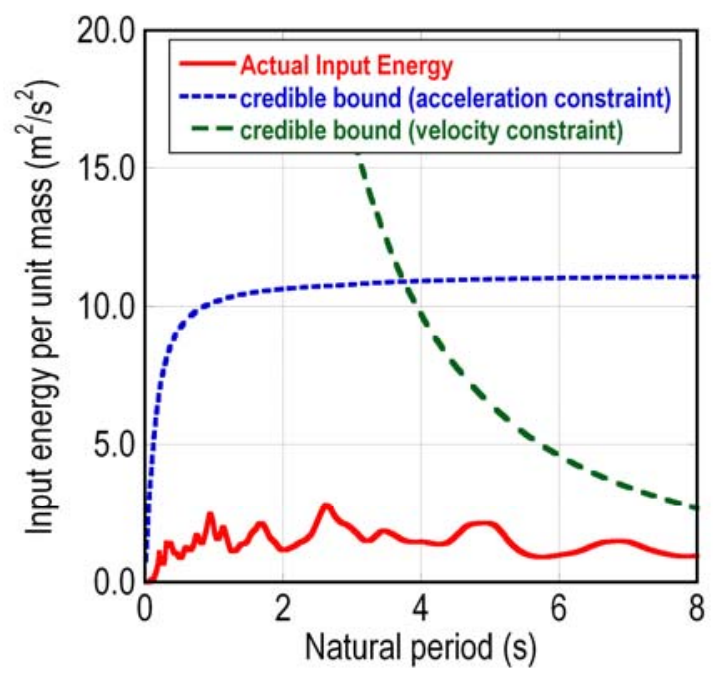

(b)

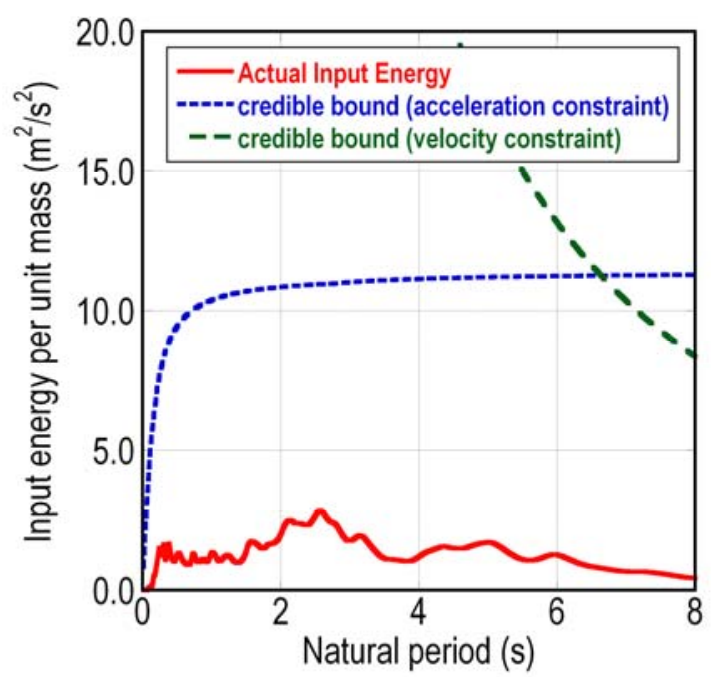

Fig.12 Actual input energies (5\% damping), the credible bounds for acceleration constraints and the credible bounds for velocity constraints for the ground motion at K-NET, Shinjuku station (TKY007): (a) NS component, (b) EW component 
(a)

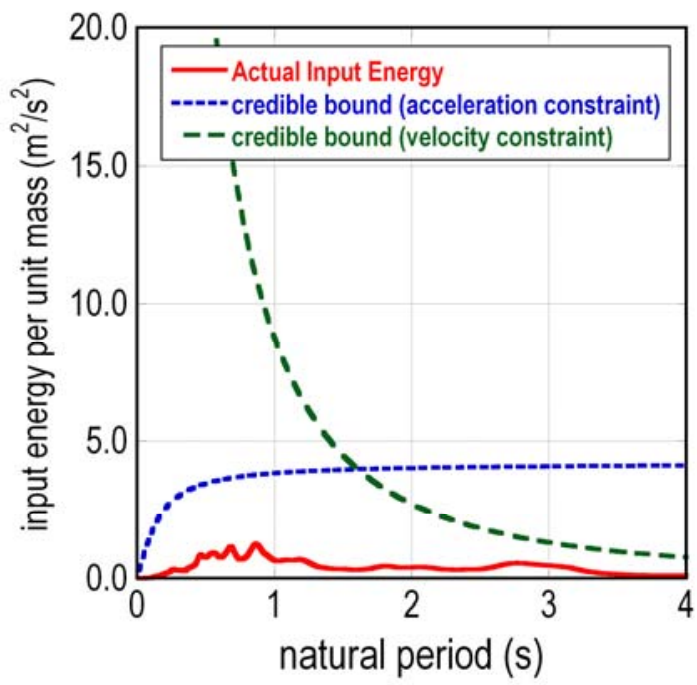

(b)

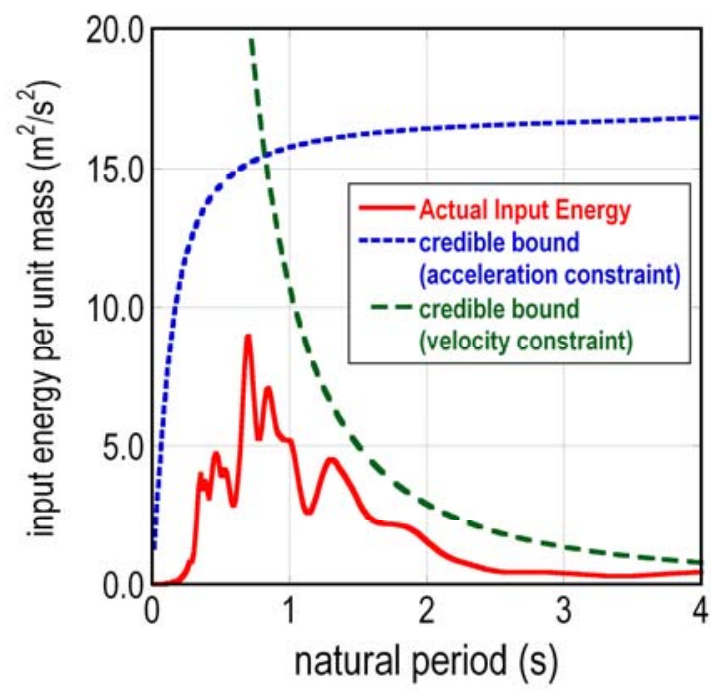

Fig.13 Actual input energies (5\% damping), the credible bounds for acceleration constraints and the credible bounds for velocity constraints for (a) El Centro NS (1940), (b) JMA Kobe NS (1995)

\section{Response simulation of super high-rise buildings in Tokyo}

In order to investigate the influence of this ground motion on high-rise buildings, two assumed buildings of 40 and 60 stories have been treated. The 40 -story building has the fundamental natural period of $\mathrm{T}_{1}=4.14 \mathrm{~s}$ and the 60 -story building has that of $\mathrm{T}_{1}=5.92 \mathrm{~s}$. The damping ratio is 0.01 . Furthermore, it is well accepted that the passive dampers are very effective in the reduction of earthquake response in high-rise buildings. The 2011 off the Pacific coast of Tohoku earthquake may be the first plate-type earthquake to have affected super high-rise buildings in mega cities. For the purpose of clarifying the merit of visco-elastic dampers (high-hardness rubber dampers (Tani et al. 2009)), the buildings of 40 and 60 stories without and with these high-hardness rubber dampers have been subjected to the long-period ground motion recorded at K-NET, Shinjuku station (TKY007).

Fig.14 shows the maximum story displacements and interstory drifts of an assumed 40 -story building of $\mathrm{T}_{1}=4.14 \mathrm{~s}$ to ground motion at Shinjuku station (TKY007) (frame response: elastic or elastic-plastic). On the other hand, Fig.15 illustrates the maximum story displacements and interstory drifts of an assumed 60-story building of $\mathrm{T}_{1}=5.92 \mathrm{~s}$ to ground motion at Shinjuku station (EW component of TKY007) (frame response: elastic-plastic, without or with high-hardness rubber dampers (Tani et al. 2009)). It can be observed that the high-hardness rubber dampers are very effective in the reduction of vibration amplitude. Fig.16 presents the comparison of time histories of top-story displacements of an assumed 60 -story building of $\mathrm{T}_{1}=5.92 \mathrm{~s}$ to ground motion at Shinjuku station (EW component of TKY007) during the 2011 off the Pacific coast of Tohoku earthquake (frame response: elastic-plastic, without or with high-hardness rubber dampers). It can be understood that the high-hardness rubber dampers can damp the building vibration in an extremely short duration.

It is reported recently (Asahi newspaper (2011b)) that a 54-story building (height $=223 \mathrm{~m}$ : fundamental natural period=6.2s (short-span direction), 5.2s (long-span direction)) with passive oil dampers in Shinjuku experienced the top displacement of 1.08(m) during the 2011 off the 
Pacific coast of Tohoku earthquake. The vibration duration was over 13 minutes. It is also stated that that building would have undergone the top displacement of 1.4(m) if the passive dampers would not have been installed. This fact corresponds well to the result explained above.


Fig.14 Maximum story displacement and interstory drift of an assumed 40-story building of $\mathrm{T}_{1}=4.14 \mathrm{~s}$ to ground motion at Shinjuku station (TKY007) during the 2011 off the Pacific coast of Tohoku earthquake (frame response: elastic or elastic-plastic)
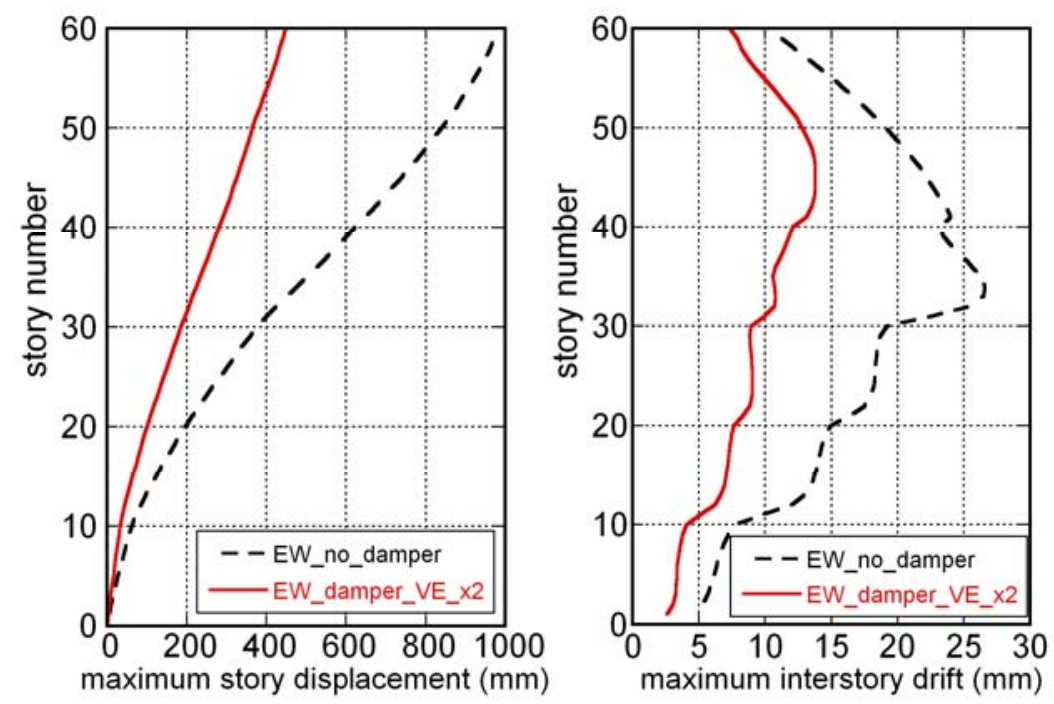

Fig.15 Maximum story displacement and interstory drift of an assumed 60-story building of $\mathrm{T}_{1}=5.92 \mathrm{~s}$ to ground motion at Shinjuku station (EW component of TKY007) during the 2011 off the Pacific coast of Tohoku earthquake (frame response: elastic-plastic, without or with high-hardness rubber dampers) 


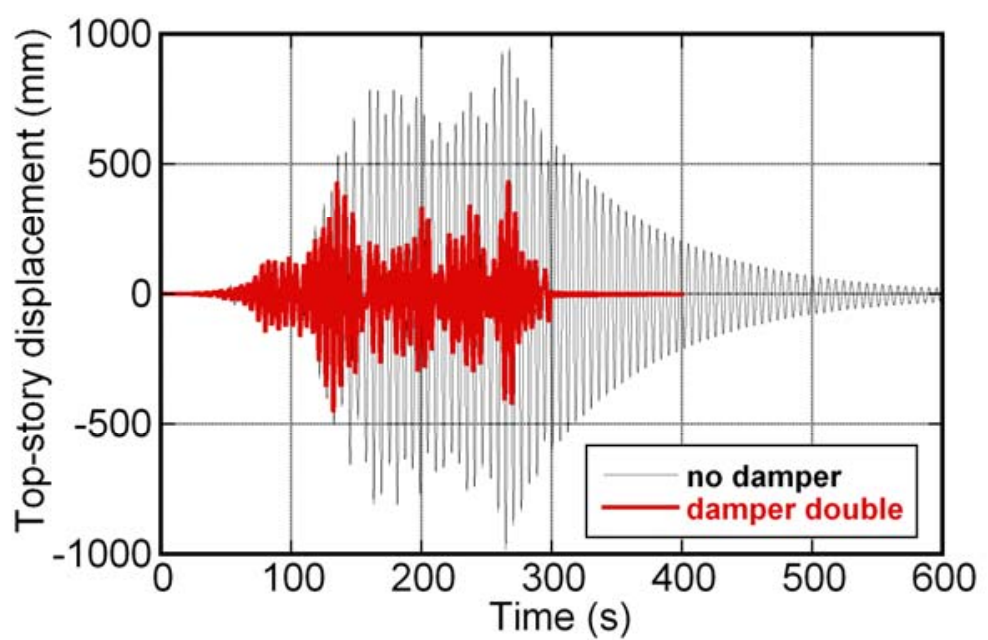

Fig.16 Comparison of time histories of top-story displacement of an assumed 60-story building of $\mathrm{T}_{1}=5.92 \mathrm{~s}$ to ground motion at Shinjuku station (EW component of TKY007) during the 2011 off the Pacific coast of Tohoku earthquake (frame response: elastic-plastic, without or with high-hardness rubber dampers)

\section{CONCLUSIONS}

The following conclusions have been obtained.

(1) The 2011 off the Pacific coast of Tohoku earthquake is the most devastating earthquake in Japan after the 1923 Great Kanto earthquake. This earthquake is the first one which attacked mega cities after the construction of super high-rise buildings. However this earthquake is not the most influential one because the influence depends on the plate (including epicenter) on which mega cities lie.

(2) The long-period ground motion recorded at K-NET, Shinjuku station (TKY007), Tokyo contains fairly large long-period wave components and has a frequency content of broad band. This can be observed from not only the velocity response spectra (and Fourier spectra) but also the earthquake input energy spectra taking into account of the concept of the critical excitation method.

(3) The high-hardness rubber dampers can damp the building vibration during long-period ground motions in an extremely shorter duration compared to the building without those dampers.

(4) The word 'unpredicted' is often used in Japan after this great earthquake. It may be true that the return period of this class of earthquakes is 500-1000 years and the use of this word may be accepted to some extent. However, the critical excitation method is expected to overcome this irrational concept in the future.

\section{ACKNOWLEDGEMENTS}

Part of the present work is supported by the Grant-in-Aid for Scientific Research of Japan Society for the Promotion of Science (No.21360267). This support is greatly appreciated. The author is grateful to Dr.S.Yoshitomi, Mr.K.Fujita and Mr.S.Murakami for conducting the energy computation to ground motions and the response analysis of assumed high-rise buildings. The use of ground motion records at K-NET is also highly appreciated. 


\section{REFERENCES}

Architectural Institute of Japan (2011). Preliminary reconnaissance report on the 2011 Off the Pacific coast of Tohoku earthquake, April 6, 2011.

Ariga, T., Kanno, Y. and Takewaki, I. (2006). Resonant behavior of base-isolated high-rise buildings under long-period ground motions. The Structural Design of Tall and Special Buildings, 15(3), 325-338.

Asahi newspaper (2011a), April 10, 2011.

Asahi newspaper (2011b), evening April 19, 2011.

Drenick, R. F. (1970). Model-free design of aseismic structures. J. Engrg. Mech. Div., ASCE, 96(EM4), 483-493.

Geller, R.J., Jackson, D.D., Kagan, Y.Y., and Mulargia, F. (1997). Earthquakes cannot be predicted. Science, 275, 1616.

Heaton, T., Hall, J., Wald, D. and Halling, M. (1995). Response of high-rise and base-isolated buildings to a hypothetical M 7.0 blind thrust earthquake, Science, 267, 206-211.

Housner, G.W. and P.C.Jennings, (1977). The capacity of extreme earthquake motions to damage structures. Structural and geotechnical mechanics edited by W.J. Hall, 102-116, Prentice-Hall Englewood Cliff, NJ.

Kamae, K, Kawabe, H and Irikura, K. (2004). Strong ground motion prediction for huge subduction earthquakes using a characterized source model and several simulation techniques, Proc. of the13th WCEE, Vancouver.

Ministry of Land, Infrastructure, Transport and Tourism (MLIT) (2010): http://www.mlit.go.jp/ report/press/house05_hh_000218.html [Accessed on January 11, 2011].

NIED (National Research Institute for Earth Science and Disaster Prevention) (2011a), '2011 Off the Pacific Coast of Tohoku earthquake, Strong Ground Motion', Emergency meeting of Headquarters for Earthquake Research Promotion, March 13, 2011. (Available from http://www.k-net.bosai.go.jp/k-net/topics/TohokuTaiheiyo_20110311/nied_kyoshin2e.pdf, [Accessed on April 20, 2011]).

NIED (2011b). (Available from http://www.hinet.bosai.go.jp/hypomap/, [Accessed on April 20, 2011]).

NIED (2011c) (Available from

http://www.kyoshin.bosai.go.jp/kyoshin/topics/html20110311144626/main_20110311144626. $\underline{\mathrm{html}}$, [Accessed on April 20, 2011]).

Stein, R.S. (2003). Earthquake conversations. Scientific American, 288(1), 72-79.

Takewaki, I. (2004). "Bound of Earthquake Input Energy." J. Struct. Engrg., ASCE, 130(9), 1289-1297.

Takewaki, I. (2006). Critical Excitation Methods in Earthquake Engineering, Elsevier.

Takewaki, I.(2008). Critical excitation methods for important structures, invited as a SemiPlenary Speaker, EURODYN 2008, July 7-9, 2008, Southampton, England.

Tani, T., Yoshitomi, S., Tsuji, M. and Takewaki, I. (2009). High-performance control of wind-induced vibration of high-rise building via innovative high-hardness rubber damper, The Structural Design of Tall and Special Buildings, 18(7), 705-728. 